\title{
Determinant of Market Share in the Indonesian Islamic Banking Industry
}

\section{Syafiq Mahmadah Hanafi*}

Faculty of Islamic Economics and Business, State Islamic University Sunan Kalijaga Yogyakarta, Indonesia

Submitted: 12 February, 2021; Accepted: 17 July, 2021; Published: 22 July, 2021

\begin{abstract}
Market share determines the position of revenue and public utilization of Sharia bank. This research aims to examine the internal and external determinant factors of Indonesia Sharia banking market share. The secondary data were obtained from the Financial Services Authority (OJK) and Bank Indonesia (BI). Autoregressive Distributive Lag (ARDL) was used to explore the short and long periods from the influence of variables, including total of offices, customers, third-party saving (DPK), and promotion. The results showed that the total number of Automated Teller Machines (ATM) had a contrastingly different impact. Therefore, this research recommends adding all variables quantitatively.
\end{abstract}

Keywords: market share, total of offices, automated teller machine (ATM), total of customers, third party saving (DPK), promotion 


\section{INTRODUCTION}

A higher growth of Sharia banking than the conventional system demonstrates the possibility of a wider market share. Public acceptance is increasing in line with broadening information and literacy of Sharia banking. Furthermore, the increased expansion of offices enhances public access, leading to the growth and acceptance of Sharia banking in 75 countries globally (Khan \& Bhatti, 2008). In general, Sharia banking has become an alternative to conventional banking. For instance, most people have made it their primary choice. Sharia banking assets have reached $\$ 1.760$ billion with 520 public offices and windows (UUS), a market share of $6 \%$, and a growth of $62 \%$ (Islamic Corporation for the Development of the Private Sector/ICD, 2019).

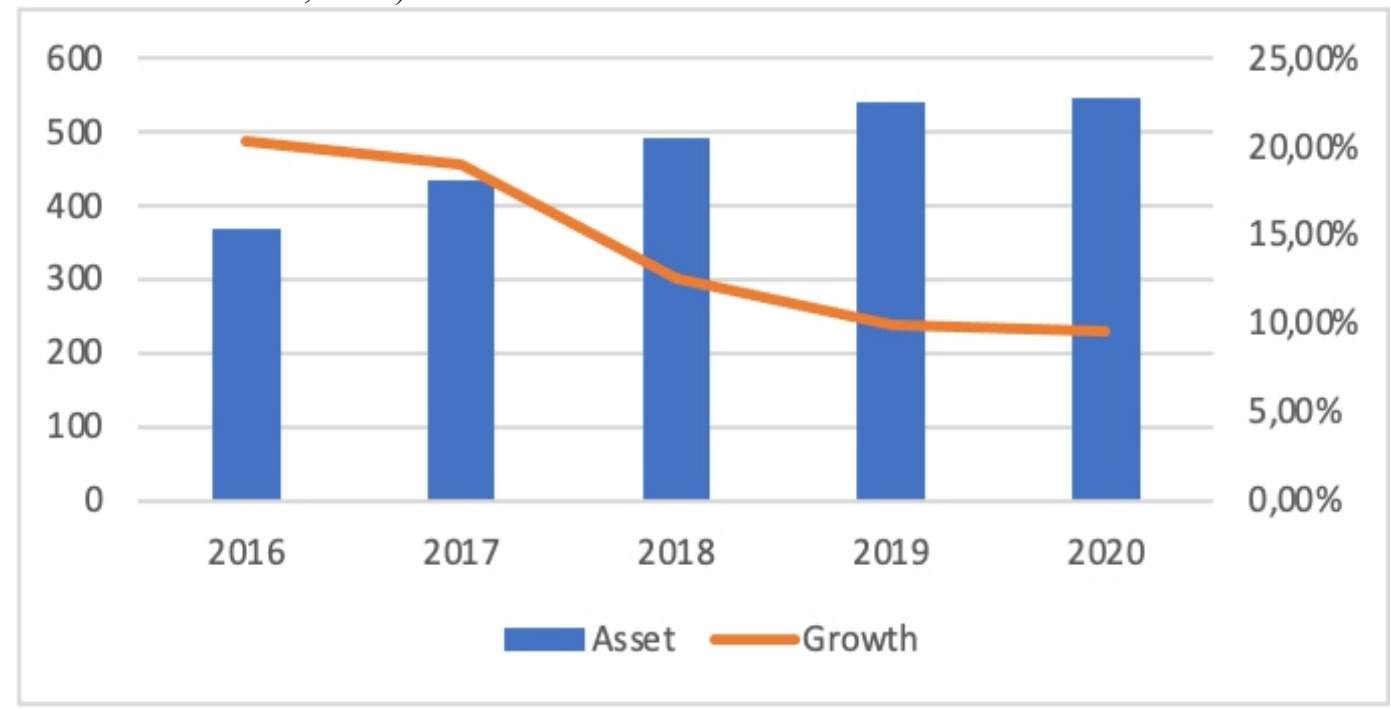

Source: OJK, 2020

Graph 1. The Assets of Sharia Bank in Indonesia

For 28 years, the public has known the strengths and weaknesses of Sharia banking. Its assets growth of $9.35 \%$ compared to last year's $9.24 \%$ is relatively higher than conventional banking, whose growth was $8.87 \%$. Subsequently, the Sharia banking assets are Rp. 545,4 trillion, with a market share of $6.18 \%$ (Otoritas Jasa Keuangan/The Financial Services Authority, 2020). Statistically, the growth of assets has been increasing, though there was a retard between 2019 and 2020. However, the journey of Sharia banking has nurtured loyal customers in Indonesia. Loyalty is shown when customers do not migrate to conventional banking. In contrast, the loyalty of Sharia banking's customers is lower than conventional banking at 22.4\% (Elena, 2020). However, Sharia banking has provenly succeeded in establishing loyalty among its customers. 


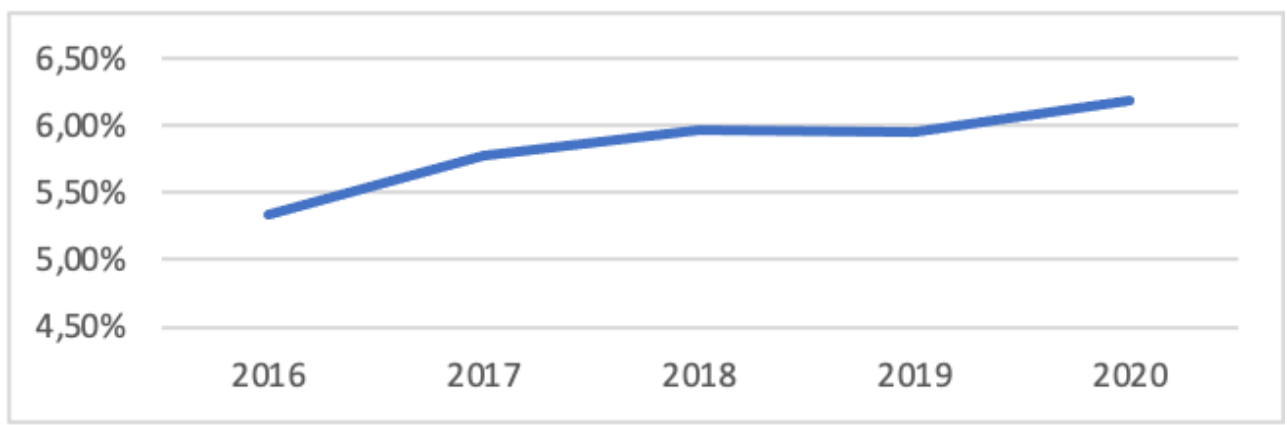

Source: OJK, 2020

Graph 2. The Growth of Islamic Bank's Market Share

The growth of Indonesia's Sharia banking market share is relatively slower than in other countries. Iran, Saudi Arabia, and Malaysia emerged as the three countries with the highest assets in 2018. Indonesia was ranked $9^{\text {th }}$ with assets worth $\$ 28$ billion (Islamic Corporation For The Development Of The Private Sector/ICD, 2019). This prompted Bank Indonesia (BI) to formulate policies to accelerate Sharia banking growth. According to the policies, UUS must be spun off after operating for 15 years (Laws No. 21 of 2008c). Moreover, the BI Regulation allows the conversion of conventional into Sharia banks, though this has been applied(PBI No. 11/10/PBI/2009). All banks are allowed to perform office channeling to Sharia banks to eliminate challenges in obtaining Sharia banking services in all regions (PBI No. 8/3/PBI/2006).

The Sharia banking market share is determined by internal or external factors. Internally, the total of Third-Party Savings (DPK) via savings and deposit shows significant access by customers to banks (Shollapur \& Baligatti, 2010; Aguirregabiria, Clark, \& Wang, 2017). A receipt of fund ownership displays the money deposited in a Sharia bank account, exhibiting its market share. Furthermore, account ownership describes accessibility by customers to a bank's products and services (Fitzpatrick, 2015). Therefore, the number of accounts affects fund deposits and shows the total number of people accessing Sharia banks. Additionally, physical offices provide opportunities for customers to access the bank for transaction purposes(Adefulu, 2015).

The recent market share improvement was facilitated by technology development that enhances wider access. Technology allows customers to access banks anytime and perform transactions effectively and efficiently. Consequently, banks strikingly compete in providing the best and free Automated Teller Machine (ATM) services (Tennant \& Sutherland, 2014). Utilizing an Automated Teller Machine (ATM) by customers could improve the bank's performance and accessibility. For instance, previous research showed that ATMs improved transactions and bank performance in Iran(Valahzaghard \& Bilandi, 2014). 
Several studies have examined market share using various measurement variables. For instance, Purboastuti, Anwar, and Suryahani (2015) examined the market share using DPK, ROA, NPF, and FDR. The results showed that DPK, ROA, and FDR had a positive impact, but NPF had a negative effect. Furthermore, Sharia banking improved its DPK and ROA and decreased its NPF to achieve a better market share. Rahman (2016) examined the effect of NPF, BOPO, CAR, and SBIS on market share. The results showed that all variables impacted market share, with BOPO and NPF having significantly higher effects in the short and long term. Moreover, Setyowati, Sartika, and Setiawan (2019) examined the market share of Islamic banking using the ROA, ROE, BOPO, and inflation variables. The results postulated that ROA and BOPO had a negative impact, ROE had a positive effect, while inflation did not affect the market share.

Sobol (2015) stated that Sharia banking could grow in European countries due to three factors. These include Muslim development, acceptance of Islamic banking as a green investment for the Non-Moslem community, and trade relations of ASEAN and Gulf countries. Valahzaghard and Bilandi (2014) analyzed the impact of technology-based financial on banking performance and market share. The findings showed that Personal Identified NumberPad (PinPad) affected performance, ATM, and Point of Selling (POS), while size impacted the market share. Furthermore, Sandy, Mulazid, and Mubarok (2018) showed that technology contributes considerably to the market share of Sharia banks in Indonesia.

Some studies analyzed the market share using directly connected variables. For instance, Nazaritehrani and Mashali (2020) stated that the internet and Telephone Banking, and POS positively affected the market share of Iranian banking. Other determining factors are the merger, expected improved performance, and interest rate (Carletti, Hartmann, \& Spagnolo, 2006). Market share becomes a vital part of banking performance in Kenya(Odunga, 2016)..

Ergungor and Moulton (2011) examined the role of branch offices in increasing the market share. The results showed that branch offices provided access to loans by middle and low-class customers. This supports Saravani, Tash, and Mahmodpour (2015), which stated that branch offices, advertising costs, and technology affected the market share of Iranian banking. Moreover, Susilowati, Purwanto, and Ermawati (2019) also Hussain, Khatoon, and Sarwar (2019) showed that branch offices are a market force that enhances convenience in transactions. Kondo research (2017) stated that local banks with many offices increase access to loans by customers and enhances payments. Additionally, branch offices increase accessibility and wider coverage of customers to banking.

Aguirregabiria et al. (2017) showed a significant relationship between total deposits and the bank's market share through loan and fund availability. Furthermore, Third-Party Fund had no impact on the market share(Wulandari \& Anwar, 2019). The relation of promotion and 
market share was analyzed by Areiqat, Mahrakani, Zamil, and Abu-Rumman (2019). The study recommended the use of a better promotion to improve the bank's market share in Jordan.

Previous studies analyzed market share, with the first group using Sharia banking performance variables, including ROA, ROE, NPF, and BOPO. The variables show the Sharia banking business performance rather than market share. The second group used variables such as ATM, branch offices, total of deposits, promotion, and technology usage. Therefore, this research uses variables depicting a relation to the achievement of Sharia bank's market share. It combines the variables of previous studies in the second group by adding the total of customers and funding products. The number of customers describes the public's use of Sharia bank products, affecting the market share. Therefore, these variables describe the market share formed in Sharia banking directly.

\section{Theoretical Background and Hypothesis Development}

Sharia banking is the customers' alternative to satisfy their financial needs based on their beliefs or religious values. It has become the savings, investment, and financing alternative for Muslims and non-Muslims. The market share is a vital factor describing the banking's performance from the competitive aspect(Abdullah, 2017). It could be influenced by certain factors, such as variables of total of offices, customers, and promotion.

A Sharia banking branch office is significant in establishing interaction with customers. It is separated from the head office to offer services to customers. Many offices ease accessibility to banking for saving, deposit, and finances(Ergungor \& Moulton 2011; Saravani et al., 2015). Moreover, dispersed branch offices provide equal opportunities for an urban or rural prospectus in accessing Sharia banking services. Therefore, the hypothesis proposed is as follows:

Ha1. Total of Sharia banking offices positively affects market share.

Automated Teller Machine (ATM) was introduced by banking with superiority in its efficiency and ease. This simple and easily accessible facility is used limitlessly to make transactions (Valahzaghard \& Bilandi, 2014). Banking has developed Joint ATM (ATM Bersama) to broaden its coverage, enabling easier, low-cost, or free customer usage in financial transactions. As a result, banking benefits through increased performance and wider access to customers. Therefore, the hypothesis assumed is as follows:

Ha2. Automated Teller Machine (ATM) positively impacts Sharia banking's market share.

The total of customers shows the number of people accessing Sharia banking. This number has recently increased by $31.89 \%$ or $12 \%$ of the total Muslim population in Indonesia, reaching 227 million people. A low number of customers significantly impacts the market share 
In comparison, a larger population with access to a bank increases market share. Moreover, the ownership of a bank account eases accessibility for other products and services (Fitzpatrick, 2015), broadening the market share. A slogan that Sharia banking is not only for Muslims but could also attract and persuade motivation, increasing customers' total. Hence, the hypothesis proposed is that:

Ha3. Total of customers positively affects Sharia banking's market share.

Sharia bank incurs promotional costs to introduce its services to the public. Socialization is related to the bank, products, services, and other access-related information. People already familiar with Sharia bank would access its products and services. Therefore, an intense and massive promotion would be deeply embedded in the public's attention and mind to access and invest in the bank (Adefulu, 2015). Promotion could be conducted through various media to achieve a wider market share successfully. Therefore, the hypothesis proposed is as follows:

\section{METHOD}

This research used secondary time-series data from Statistics of Sharia Banking by The Financial Services Authority (OJK). Data were collected every month between June 2014 and October 2020. Table 1 describes some terms and operational definitions used in this study:

Table 1. Operational Definition of Variables

\begin{tabular}{ll}
\hline \multicolumn{1}{c}{ Terms } & \multicolumn{1}{c}{ D efinition and measurement } \\
\hline $\begin{array}{l}\text { Market share of Sharia } \\
\text { banking (MSHR) }\end{array}$ & $\begin{array}{l}\text { It is the ratio of total of Sharia banking assets, comprising } \\
\text { Sharia Business Entity (BUS) and Sharia Business Unit } \\
\text { (UUS) to the total of national banking assets. }\end{array}$ \\
$\begin{array}{l}\text { Natural log of total of } \\
\text { Tharia banking offices } \\
\text { (LNOFC) }\end{array}$ & $\begin{array}{l}\text { branch, supporting branch, and cash offices. It is transformed } \\
\text { into a natural log. }\end{array}$ \\
Natural log of total of & Total of Automated Teller Machine (ATM) Is specific for Sharia \\
Automated Teller & Business Entity (BUS) and Sharia Business Unit (UUS) dispersed \\
Machine (LNATM) & throughout Indonesia. It is transformed into a natural log. \\
Natural log of total of & The total of Sharia banking customers is the number of accounts \\
Sharia banking & for funding products. It is transformed into a natural log. \\
customers (LNNAS) & \\
The ratio of promotion & It measures the marketing efficiency of Sharia banking \\
cost to total of revenue & products. \\
(PRO) &
\end{tabular}

This study examines the Sharia banking market share determinants using Third-Party Fund (DPK) as a control variable. Previous studies showed that DPK affects the performance and market share of Sharia banks. Therefore, the hypotheses in this study were tested using the time-series data. Cointegration degree (a long-term relationship) is the fundamental issue in the 
time-series analysis method. A cointegrated variable within the level was notated with $\mathrm{I}(0)$, while a variable within the level of the first difference was indicated as I(1). When variables in the regression equation were not $\mathrm{I}(0)$, their linear combination was made stationary to fulfill the I(1) condition.

Vector Autoregressive (VAR) and Error Correction Model (ECM) have been developed to accommodate stationary and cointegration degrees (Engle \& Granger, 1987; Harris \& Sollis, 2003). However, their limitation is the similarity of cointegration degree between variables in an equation. Therefore, Autoregressive Distributed Lag (ARDL) model is more flexible in assessing the I(0) or I(1) conditions (Pesaran, Shin, \& Smith, 2001). This explains why it was widely used in previous studies (Alhassan \& Fiador, 2014; Bhattacharya, Bhattacharya, \& Basu, 2019; Mustafa, Ramlee, \& Kassim, 2016). ARDL is illustrated as follows (Pesaran, 2015):

$$
\Delta \mathrm{Y}_{\mathrm{t}}=\beta_{0}+\beta_{1} \mathrm{Y}_{\mathrm{t}-1}+\beta_{2} \mathrm{X}_{\mathrm{t}-1}+\quad{ }_{\mathrm{i}=1}^{\mathrm{p}} \delta_{1} \Delta \mathrm{Y}_{\mathrm{t}-\mathrm{i}}+\quad{ }_{\mathrm{i}=1}^{\mathrm{q}} \delta_{2} \Delta \mathrm{X}_{\mathrm{t}-\mathrm{i}}+
$$

where $\Delta Y \mathrm{t}$ is the first difference of Yt, Yt-1 is the lag of $\mathrm{Yt}, \mathrm{Xt}-1$ is the lag of one period from the vector of independent variable $\mathrm{Xt}, \Delta \mathrm{Yt}-\mathrm{i}$ is the lag of $\mathrm{p}$ period from $\Delta \mathrm{Yt}, \Delta \mathrm{Xt}-\mathrm{i}$ is the lag of $\mathrm{q}$ period from $\Delta \mathrm{Xt}$, and $\varepsilon t$ is the error term.

The length of the optimal lag period is crucial in time-series modeling. The criteria of Akaike Information Criterion (AIC) and Schwarz Information Criterion (SIC) were used to determine the combination of $\mathrm{p}$ and $\mathrm{q}$ in the ARDL. The validity test was determined from the cointegration (the long-term relation) with the Bound test. A value of $F$ greater than the critical bound in I (0) and I(1) means that the ARDL model is valid. However, when F falls between two values of such critical bound, the validity is determined by testing its significance from the coefficient of error correction term (ECT) (Shrestha \& Chowdhury, 2007). ECT represents the adjustment acceleration to achieve a long-term equilibrium. Therefore, the coefficient of ECT is expected as significantly negative.

The basic ARDL is estimated using the ordinary least square method. Some assumptions, such as homoscedastic, non-autocorrelation, and stability, must be satisfied to ensure the efficiency and consistency of regression parameters. Therefore, a respective assumption is tested by the White, Breusch-Godfrey, Cumulative Sum of Residuals (CUSUM) and Cumulative Sum of Square Residuals (CUSUMSQ) method. Particularly, CUSUM and CUSUMSQ are selected one or both (Brooks, 2014). The ARDL equation model used in this research is as follows:

$$
\begin{aligned}
& \Delta \text { MSHR }=\beta_{0}+\beta_{1} \text { MSHR }_{-1}+\beta_{2} \text { LNOFG }_{-1}+\beta_{3} \text { LNATM }_{-1}+\beta_{4} \text { LNNAS }_{-1}+\beta_{5} \text { LNDPK }_{-1}+\beta_{6} \text { PRO }_{\mathrm{t}-1}+ \\
& \underset{\mathrm{i}=1}{\mathrm{p}} \beta_{1} \Delta \text { MSHR }_{\mathrm{t}-\mathrm{i}}+\underset{\mathrm{i}=1}{\mathrm{q} 1} \beta_{2} \Delta \mathrm{LNOFG}_{\mathrm{t}-\mathrm{i}}+\underset{\mathrm{i}=1}{\mathrm{q} 2} \beta_{3} \Delta \text { LNATM }_{-\mathrm{i}}+\underset{\mathrm{i}=1}{\mathrm{q} 3} \beta_{4} \Delta \text { LNNAS }_{-\mathrm{i}}+ \\
& \underset{\mathrm{i}=1}{\mathrm{q} 4} \beta_{5} \Delta \mathrm{LNDPK}_{\mathrm{t}-\mathrm{i}}+\underset{\mathrm{i}=1}{\mathrm{q} 5} \beta_{6} \Delta \mathrm{PRO}_{\mathrm{t}-\mathrm{i}}+\varepsilon_{\mathrm{t}}
\end{aligned}
$$


The primary requirement before estimating the ARDL model was the stationary test. Each variable had to be stationary in the level and first difference. The assumption was tested using Augmented Dickey-Fuller (ADF) and Phillip-Perron (PP) methods involving intercept and trend, or intercept. This was aimed to accommodate the tendency of the trend to time. Furthermore, the ARDL model was used to predict the short and long term in the Sharia banks' market share. It is a regression model of present and past values of market share, number of offices, ATMs, customers, and promotions.

\section{RESULT AND DISCUSSION}

Table 2 shows descriptive statistic information from all variables in the level or first difference. The mean of market share (MSHR) in Sharia banking is 5.41\%. Similarly, the mean of monthly changes of the market share was $0.02 \%$. This indicates that, although the market share was low, the monthly addition increased. Based on JB-Stat and P(JB Stat.), most variables were not normally distributed.

Table 2. Descriptive Statistic of Variables in the Level and First Difference

\begin{tabular}{cccccccc}
\hline & Obs. & Mean & Stdv. & Max. & Min. & JB Stat. & P(JB Stat.) \\
\hline MSHR & 76 & 5.41 & 0.58 & 6.33 & 4.56 & 7.32 & 0.03 \\
$\Delta$ MSHR & 76 & 0.02 & 0.10 & 0.35 & -0.19 & 7.05 & 0.03 \\
LNOFC & 76 & 7.73 & 0.05 & 7.86 & 7.58 & 4.49 & 0.11 \\
$\Delta$ LNOFC & 76 & 0.00 & 0.02 & 0.11 & -0.11 & 1516.66 & 0.00 \\
LNATM & 76 & 8.01 & 0.15 & 8.23 & 7.65 & 3.23 & 0.20 \\
$\Delta$ LNATM & 76 & 0.00 & 0.08 & 0.40 & -0.39 & 589.63 & 0.00 \\
LNNAS & 76 & 17.06 & 0.25 & 17.54 & 16.64 & 2.18 & 0.34 \\
$\Delta$ LNNAS & 76 & 0.01 & 0.03 & 0.17 & -0.16 & 585.67 & 0.00 \\
LNDPK & 76 & 12.61 & 0.26 & 13.04 & 12.18 & 6.35 & 0.04 \\
$\Delta$ LNDPK & 76 & 0.01 & 0.02 & 0.07 & -0.03 & 14.24 & 0.00 \\
PRO & 76 & 0.85 & 0.62 & 4.85 & 0.20 & 1797.17 & 0.00 \\
$\Delta$ PRO & 76 & -0.03 & 0.76 & 2.15 & -3.66 & 201.19 & 0.00 \\
\hline
\end{tabular}

Table 2 shows a descriptive statistic of all variables of Sharia banking asset market share (MSHR), natural log of total of offices (LNOFC), natural log of total of ATMs (LNATM), natural log of total of customers in Third-Party Savings (LNNAS), and the ratio of promotion cost to total of revenue of Sharia banking (PRO). Additionally, the component of descriptive statistics included mean, standard deviation (Stdv.), maximum value (Max.), minimal value (Min.), statistic value of Jarque-Berra (JB Stat.), and probability of JB-Stat. P (JB Stat.) in testing data distribution. When the significant ( $\mathrm{P}$ (JB Stat.) was $<5 \%, \mathrm{H} 0$ was rejected, meaning that the data were normally distributed. 
The assumption of stationery is crucial in time-series regression analysis. Table 3 presents the stationary test for each variable in the level or first difference. The ADF and PP test results show that only PRO achieved its stationarity in the level and first difference. Therefore, the ARDL model became the best choice because not all variables achieved their stationary in the same mode.

Table 3. The Root Unit Test Results

\begin{tabular}{ccccc}
\hline & \multicolumn{2}{c}{ ADF } & \multicolumn{2}{c}{ PP } \\
& Intercept & $\begin{array}{c}\text { Intercept } \& \\
\text { trend }\end{array}$ & Intercept & $\begin{array}{c}\text { Intercept \& } \\
\text { trend }\end{array}$ \\
\hline MSHR & 0.06 & -3.09 & -0.08 & -2.96 \\
$\Delta$ MSHR & $-7.09^{* * *}$ & $-7.12^{* * *}$ & $-10.18^{* * *}$ & $-10.21^{* * *}$ \\
LNOFC & -2.43 & -1.50 & -2.23 & -1.52 \\
$\Delta$ LNOFC & $-7.63^{* * *}$ & $-8.57^{* * *}$ & $-13.86^{* * *}$ & $-14.88^{* * *}$ \\
LNATM & $-2.81^{*}$ & -3.10 & $-2.63^{*}$ & -2.88 \\
$\Delta$ LNATM & $-6.07^{* * *}$ & $-6.03^{* * *}$ & $-7.80^{* * *}$ & $-7.75^{* * *}$ \\
LNNAS & -0.17 & -2.60 & -0.27 & -2.74 \\
$\Delta$ LNNAS & $-6.06^{* * *}$ & $-6.04^{* * *}$ & $-9.11^{* * *}$ & $-9.07 * * *$ \\
LNDPK & -0.33 & -1.94 & -0.37 & -2.19 \\
$\Delta$ LNDPK & $-6.77^{* * *}$ & $-6.71^{* * *}$ & $-10.23^{* * *}$ & $-10.16^{* * *}$ \\
PRO & $-9.23^{* * *}$ & $-8.92^{* * *}$ & $-6.84^{* * *}$ & $-7.06^{* * *}$ \\
$\Delta$ PRO & $-9.06^{* * *}$ & $-9.05^{* * *}$ & $-17.33^{* * *}$ & $-17.62^{* * *}$ \\
\hline
\end{tabular}

Table 3 displays the root unit test results using Augmented Dickey-Fuller (ADF) and PhillipPerron (PP) methods. The test involved inserting intercept and intercept and trend, in which data was tested in the level $(\mathrm{x})$ and first difference $(\Delta \mathrm{x})$. Furthermore, the variables tested were the Sharia banking asset market share (MSHR), natural log of total of offices (LNOFC), natural log of total of ATMs (LNATM), natural log of total of customers in Third-Party Savings and finance (LNNAS), and the ratio of promotion cost to total of revenue of Sharia banking (PRO). Therefore, the hypothesis of the root unit test (H0) showed that the data was nonstationer. ***; and $* * *$ significant respectively in the critical value of $10 \%, 5 \%$, and $1 \%$.

The next step was the interpretation of ARDL estimation, where the optimal lag was determined by the AIC and SIC criteria. Both criteria recommended ARDL $(1,0,0,0,1,0)$. The parameter estimation result was then transformed to the short- and long-term form, as depicted in Table 4. Furthermore, the $\mathrm{C}$ and $\mathrm{D}$ panel reported the model specification and stability test (CUSUM and CUSUMQ). The parameter value of the Bound test was 3.87, greater than the stipulated critical value as of [2.26 - 3.35]. This indicated the presence of a long-term relationship (cointegration). Additionally, the coefficient of error correction (EC) was -32.42 and significant. Therefore, the market share and its determinant achieved the equilibrium point of the long-term relationships through its adjustment mechanism. Moreover, the assumption 
test of homoscedastic and non-autocorrelation (B-G, LM, and White test) supported H0. The model stability test shows that the CUSUM graphic was stable with a confidence degree of $95 \%$. However, it seemed unstable in certain periods and out of a confidence degree of $95 \%$. According to Brooks (2014), when one indicator satisfies the assumption, the ARDL model is stable.

Table 4. The Estimation Results of the ARDL Model

\begin{tabular}{l} 
Panel A. Long-term \\
\hline LNOFC \\
\hline LNATM
\end{tabular}

LNOFC: natural log of total of offices; LNATM: natural log of total of ATMs; LNNAS: natural log of total of customers in Third-Party Savings and finance; PRO: ratio of promotion cost to total of revenue. The bound test determines the ARDL model validity in the significance of $5 \%$, using the threshold of F-stat. as [2.26-3.35]. B-G LM (Breusch-Godfrey Lagrange Multiplier) test examines the non-autocorrelation assumption. Furthermore, the test analyzes homoscedastic assumptions. B-G LM and White test is based on the Chi-Square distribution. Both CUSUM and CUSUMQ tests determine the stability of the T-statistic model.

The specification and stability test results show that the ARDL model is valid, consistent, and could be interpreted:

First, the LNOFC coefficient was significantly positive in the short-term equation, indicating that more offices increase the market share of Sharia banking. Total of offices 
physically provides easy access for customers, especially financing. Furthermore, a total of sufficient and easily accessible offices enables customers to utilize products and services efficiently and effectively. Branch offices separate from the head office ease customers' access to similar quality banking services. These results support (Ergungor \& Moulton, 2011; Saravani et al., 2015). A dispersed and equally distributed total of offices allows the public to use banking products easily (Saravani et al., 2015). Additionally, several branches act as market power and provide convenience in bank transaction (Susilowati, et. al., 2019). According to Kondo (2017), local banks with many offices increase micro customers' access to loans and payments. Also, they provide an equal chance for limitless access by the public in urban or rural areas. Therefore, the total of existing offices should be maintained or increased to improve the market share of Sharia bank.

Second, the total of ATMs (LNATM) in Sharia banking had no impact on increasing the market share, as seen from the insignificant LNATM coefficient. ATM is the basic need of customers to withdraw money limitlessly. Therefore, most Sharia and conventional banks provide Joint ATM (ATM Bersama) via inter-banks collaboration. Through this collaboration, Joint ATM (ATM Bersama) is accessed by the ATM holder from any bank with no limitations. However, these results contradict Valahzaghard and Bilandi (2014), which stated that ATM affects market share. In line with this, Sandy et al., (2019) and Hussain et al., (2019) showed that technological development in Sharia banking increases the market share.

Third, the total of customers (LNNAS) coefficient was significantly negative in the short-and-long-term equation. This means that the greater number of customers using the products, the higher the market share achieved by Sharia banking. The total of customers shows the number of people accessing the banking products and services. Therefore, customer addition shows the relation in using the products to fulfill their financial need. Moreover, the total determines the market share through the number of customers depositing their funds for giro or savings. The increased assets of Sharia bank depict the loyalty of customers to use its products (Maulan, 2016; \& Ireland, 2018). This loyalty is shown in the products' legality and the reluctance to switch to conventional banks, which are more beneficial. The largest banking assets in Indonesia were 1,447.85 trillion and 1,405.85 trillion, obtained by BRI and Bank Mandiri, respectively. They were supported by 70 million (for BRI) and 83 million (for Bank Mandiri) customers (Aninda, 2018; \& Rahayu, 2019). These results show that a higher market share of Sharia bank could be achieved by improving and increasing the number of customers.

Fourth, the promotion had a positive impact on the short-and-long-term equation, as measured from the cost ratio to the monthly revenue. Promotion is conducted through various 
media targeting all levels of the public and regions (Kasie \& Gloria, 2018). However, literacy on Sharia banking was still low, meaning that socialization and promotion are crucial since they improve the market share. This is achieved by improving customer knowledge and information about Sharia banking as a financial institution and product and service provider. As a result, the public uses banking for their financial needs, improving market share. These results support Adefulu (2015) the impacts of banking access via promotion. Therefore, Sharia banking should improve its promotion to boost its market share. However, these findings contradict Areiqat et al., (2019), which stated that promotion did not impact the market share. Also, the market share could be improved by increasing the promotion cost of Sharia bank. Areiqat et al., (2019) showed the impact of adequate promotion and the negative effect of retention on market share in Jordan.

\section{CONCLUSION}

The market share of Sharia bank is measured from its total of branch offices, the number of ATMs, the total of customers, and promotion as the direct determining variables. The result shows that the total of offices and customers, Third-Party Savings, and promotion costs affect the short-and long-term market share. However, the number of ATMs does not affect the market share since Joint ATM (ATM Bersama) is used by ATM cardholders.

These results show that the market share of Sharia bank could be improved by increasing the total of offices and customers, Third-Party Savings, promotion cost, and a total of ATMs. Therefore, further research should analyze the market share with these variables by comparing Sharia and conventional banks.

\section{BIBLIOGRAPHY}

Abdullah, A. (2017). A Comparison between Malaysia and Indonesia in Islamic Banking Industry. Research Journal of Business and Management, 4(3), 276-286. https://doi.org/10.17261/pressacademia.2017.705.

Adefulu, A. D. (2015). Promotional Strategy Impacts on Organizational Market Share and Profitability. Economica, 11(6), 20-33.

Aguirregabiria, V., Clark, R., \& Wang, H. (2017). The Geographic Flow of Bank Funding and Access to Credit: Branch Networks and Local-Market Competition. Working Paper.

Alhassan, A. L., \& Fiador, V. (2014). Insurance-growth Nexus in Ghana: An Autoregressive Distributed Lag Bounds Cointegration Approach. Review of Development Finance, 4(2), 83-96. https://doi.org/10.1016/j.rdf.2014.05.003. 
Areiqat, A. Y., Mahrakani, N. J., Zamil, A. M., \& Abu-Rumman, A. (2019). The Role of Strategies for Promoting Relations between Banks and Customers, and Their Impact on Customer Retention and The Market Share of Jordanian Commercial Banks. Academy of Accounting and Financial Studies Journal, 23(5), 1-10.

Bhattacharya, S. N., Bhattacharya, M., \& Basu, S. (2019). Stock Market and its Liquidity: Evidence from ARDL Bound Testing Approach in the Indian Context. Cogent Economics and Finance, 7(1), 1-12. https://doi.org/10.1080/23322039.2019. 1586297.

Brooks, C. (2014). Introductory Econometrics for Finance: Third Edition. Glasgow: Cambridge University Press.

Carletti, E., Hartmann, P., \& Spagnolo, G. (2006). Bank Mergers, Competition, and Liquidity. Center for Financial Studies Working Paper No. 2006/08. 1-49.

Engle, R. F., \& Granger, C. W. J. (1987). Co-integration and Error Correction: Representation, Estimation, and Testing. Econometrica, 55(2), 251-276. https://doi.org/10.2307/ 1913236.

Ergungor, O. E., \& Moulton, S. (2011). Do Bank Branches Matter Anymore? Economic Commentary (Federal Reserve Bank of Cleveland), 2011(13), 1-6. https://doi.org/10. 26509/frbc-ec-201113.

Fitzpatrick, K. (2015). The Effect of Bank Account Ownership on Credit and Consumption: Evidence from the UK. Southern Economic Journal, 82(1), 55-80. https://doi.org/10.1002/soej.12054.

Greene, W. H. (2018). Econometric Analysis, $8^{\text {th }}$ Edition. New York: Pearson Education.

Harris, R., \& Sollis, R. (2003). Applied Time Series Modelling and Forecasting. New Jersey: John Wiley \& Sons.

Hussain, H., Khatoon, S., \& Sarwar, Z. (2019). Competitive Strategies of Islamic Banks: A Case of Pakistan. Journal of Philosophy, Culture and Religion, 46, 12-23. https://doi.org/10.7176/jpcr/46-02.

Ireland, J. J. (2018). Just How Loyal Are Islamic Banking Customers? International Journal of Bank Marketing, 36(3), 410-422. https://doi.org/10.1108/02652323199400002.

Islamic Corporation for The Development of The Private Sector (ICD). (2019). Islamic Finance Development Report-2019 “Shifting Dynamics.” ICD-Refinitiv, 1-68.

Kasie, E. G., \& Gloria, C. E. U. (2018). The Influence of Promotional Strategies on the Performance of Nigerian Banks. A Study of Selected Banks in Nigeria. International Journal of Trend in Scientific Research and Development, 3(1), 278-286. https://doi.org/10.31142/ijtsrd18939. 
Khan, M, M., \& Bhatti, M. I. (2008). Islamic Banking and Finance: on its Way to Globalization. Managerial Finance, 34(10), 708-725. https://doi.org/10.1108/03074350810891029.

KNKS. (2020). Trend Konversi ke Bank Syariah: Tingkatkan Efisiensi dan Produktivitas Bisnis. Insight: Buletin Ekonomi Syariah, 8(1). 1-18.

Kondo, K. (2017). Does Branch Network Size Influence Positively the Management Performance of Japanese Regional Banks?. Munich Personal RePEc Archive Paper No. 81257, 1-22.

Maulan, S. (2016). Consumer's Loyalty toward Islamic Banking System: Does Halal Brand Awareness Matter?. International Journal of Economics, Management, and Accounting, 24(2), 209-226.

Mustafa, S. A., Ramlee, R., \& Kassim, S. H. (2016). Behavior of the Islamic Stock Market in a Prolonged Downturn in the Global Market: Empirical Evidence from Malaysia. Journal of Islamic Finance, 4(2), 67-76. https://doi.org/10.12816/0024089.

Nazaritehrani, A., \& Mashali, B. (2020). Development of E-Banking Channels and Market Share in Developing Countries. Financial Innovation, 6(1). 2-19. https://doi.org/10.1186/s40854-020-0171-z.

Odunga, R. M. (2016). Specific Performance Indicators, Market Share and Operating Efficiency for Commercial Banks in Kenya. International Journal of Finance and Accounting, 5(3), 135-145.https://doi.org/10.5923/j.ijfa.20160503.01

Pesaran, M. H. (2015). Time Series and Panel Data Econometrics. Oxford University Press.

Pesaran, M. H., Shin, Y., \& Smith, R. J. (2001). Bounds Testing Approaches to The Analysis of Level Relationships. Journal of Applied Econometrics, 16(3), 289-326. https://doi.org/10.1002/jae.616.

Purboastuti, N., Anwar, N., \& Suryahani, I. (2015). Pengaruh Indikator Utama Perbankan Terhadap Pangsa Pasar Perbankan Syariah. Jejak, 8(1), 13-22. https://doi.org/10.15294/jejak.v8i1.3850

Rahman, A. (2016). Analisis Faktor-Faktor yang Mempengaruhi Market Share Bank Syariah. Journal Analytica Islamica, 5(2), 291-314.

Sandy, M., Mulazid, A. S., \& Mubarok, F. (2019). An Analysis on the Effect of Performance Factors and Technology Aspect on Market Share of Sharia-Compliant Banking in Indonesia. Proceedings of the 2018 International Conference on Islamic Economics and Business (ICONIES), 370-375, https://doi.org/10.2991/ iconies-18.2019.73.

Saravani, Z., Tash, M. N. S., \& Mahmodpour, K. (2015). Evaluation of Bank Market Share and its Affective Determinants: Sepah Bank. International Research Journal of Applied and Basic Sciences, 9(7), 1003-1009. 
Setyowati, D. H., Sartika, A., \& Setiawan. (2019). Faktor-Faktor Yang Mempengaruhi Pangsa

Pasar Industri Keuangan Syariah Non-Bank. Jurnal Iqtisaduna, 5(2), 169-186. https://doi.org/10.24252/iqtisaduna.v5i2.10986.

Shollapur, M. R., \& Baligatti, Y. G. (2010). Funds Management In Banks: A Cost-Benefit Perspective. International Business and Economics Research Journal, 9(11), 21-30. DOI: 10.19030/iber.v9i11.27.

Shrestha, M. B., \& Chowdhury, M. K. (2007). Testing Financial Liberalization Hypothesis with ARDL Modeling Approach. Applied Financial Economics, 17(18), 1529-1540. https://doi.org/10.1080/09603100601007123.

Sobol, I. (2015). Islamic Banking in the European Union Countries. European Integration Studies, 9, 184-197. https://doi.org/10.5755/j01.eis.0.9.12806.

Susilowati, E., Purwanto, B., \& Ermawati, W. J. (2019). Market Power and Efficiency of Commercial Banks in Indonesia. Jurnal Manajemen, 23(1), 133-151. https://doi.org/10.24912/jm.v23i1.455.

Tennant, D., \& Sutherland, R. (2014). What Types of Banks Profit Most from Fees

Charged? A Cross-Country Examination of Bank-Specific and Country-Level Determinants. Journal of Banking and Finance, 49, 178-190. https://doi.org/10.1016/ j.jbankfin.2014.08.023.

Valahzaghard, M. K., \& Bilandi, E, B. (2014). The Impact of Electronic Banking on Profitability and Market Share: Evidence from Banking Industry. Management Science Letters, 4, 2531-2536. https://doi.org/10.5267/j.msl.2014.11.003.

Wooldridge, J. M. (2018). Introductory Econometrics (7th Edition). Cengage Learning, Inc.

Wulandari, V., \& Anwar, D. (2019). Analisis Pengaruh Dana Pihak Ketiga dan Pembiayaan terhadap Market Share Perbankan Syariah di Indonesia Melalui Aset Sebagai Variabel Intervening. Serambi: Jurnal Ekonomi Manajemen dan Bisnis Islam, 1(2), 33-44. https://doi.org/10.36407/serambi.v1i2.69.

\section{Regulations:}

Undang-Undang Nomer 21 Tahun 2008 Tentang Perbankan Syariah.

Peraturan Bank Indonesia Nomor 8/3/PBI/2006 tentang Perubahan Kegiatan Usaha Bank Umum Konvensional Menjadi Bank Umum yang Melaksanakan Kegiatan Usaha Berdasarkan Prinsip Syariah dan Pembukaan Kantor Bank yang Melaksanakan Kegiatan Usaha Berdasarkan Prinsip Syariah oleh Bank Umum Konvensional.

Peraturan Bank Indonesia Nomor 11/10/PBI/2009 tentang Unit Usaha Syariah. 


\section{Websites:}

Aninda, N. (2018). Hampir Separuh Nasabah BRI Generasi Milenial. Retrieved from https://finansial.bisnis.com/read/20180919/90/840148/hampir-separuh-nasabah-brigenerasi-milenial.

Elena, M. (2020). Loyalitas Nasabah Tinggi, Bank Syariah Diyakini Tetap Tumbuh - Finansial Bisnis. Retrieved from https://finansial.bisnis.com/read/20200315/231/1213468/ loyalitas-nasabah-tinggi-bank-syariah-diyakini-tetap-tumbuh-.

Otoritas Jasa Keuangan. (2020). Snapshot Perbankan Syariah Indonesia Juni 2020. Otoritas Jasa Keuangan, 1-6. https://www.ojk.go.id/id/kanal/syariah/berita-dankegiatan/publikasi/Pages/Snapshot-Perbankan-Syariah-Juni-2020.aspx

Rahayu, Y. A. (2019). Layani 83,5 Juta Nasabah, Bank Mandiri Catat 4.143 Transaksi Per Menit. Retrieved from https://www.merdeka.com/uang/layani-835-juta-nasabahbank-mandiri-catat-4143-transaksi-per-menit.html. 